\title{
The effect of game on pre-school period (ages 3-6): a review of study
}

\author{
Ozgur GUL
}

Faculty of Sport Sciences, Selçuk University, Konya, Turkey (e-mail: ozgurgul@selcuk.edu.tr).

\begin{abstract}
Game which is very efficient in each period of a child's development has a great importance. That is, game which is such an effective resource to facilititate his harmony with the outside world, contributes to discover a child's environment, be aware of his abilities when making new experiences and increase them, express his emotions and opinions when speaking, communicate with his environment, adopt some social roles. In this study, it was focused on the importance of game for children in the period which involves the ages 3-6, is called "Pre-School Period", in other words, "Game Period". The relevant literature was studied, based on the study findings about this period; a theoretical basis was presented about the effect of game on this period and evaluated as well. In light of this information, when considering the development levels of pre-school children, game must be given necessary importance for children to be healthier in every aspect. The characteristics to be given to children must be provided to them in amusing ways, that is, games as entertaining items of children. Depending on this, all activities must be done in a game format, not only game activities.
\end{abstract}

Keywords: Child; game; game period; importance of game.

\section{INTRODUCTION}

Plays are fundamentals of physical, cognitive, linguistic, emotional and social developments which children involve in willingly and enjoyably, parts of real life and an effective process of learning. For centuries, they have been analyzed by theorists. While play and toy features are influenced by children's development, these affect their development as well. Dramatic representations start in children aged two. Owing to dramatic representations with adult mimics and creative items, children solve dependenceindependence conflicts and acquire self-control. Also, they check the relevant frontiers in their real lives and consolidate the concepts of right-wrong by repeating the events they see and experience in their environment. Between the ages of 2-4, utterances and symbolic thoughts develop. Concordantly, children talk with things and various objects. Symbolic plays make children ask questions and have answers. In the end, children's opinion system improves (6).

Plays are basic events which go on from birth to death. The changing one is only a way of playing. Especially, they are very significant in children at the development period; it has a certain importance in each age group and each play type as functional necessities of play, though. At first, plays are needs for children. They are methods which fulfill their movement needs. While playing, children are under two effects. The first one is their family, natural and cultural environment, the second one is their genetic intelligence, their perceptual, interpretative, creative and social reaction characteristics. Therefore, play is the best way in recognizing and analyzing children according to many scientists. For example, Freud and Piaget describe play as a window open to a child's mind in their child development theories. That is, a child's mental condition dynamics, mental structure, coherent situation in evaluation of social events are reflected on plays. It is possible to observe and examine during plays (17).

In accordance with the education science, the most effective way in children's education is play. Children learn behaviours, information, skills, etc. necessary for life from plays by themselves. They perceive, adapt and reinforce the events of building a relationship with people, talking, helping, obtaining information, forming habits, having experiences and understanding roles of life (such as mother-father, female-male, teacherstudent). Children's personalities appear and 
develop in plays more clearly. Their abilities can be seen in plays in a better way and their development can be guided (31).

Plays are instinctive activities which occur without any external effects and pressures by themselves. Children run, play, smile, shout and climb in these activities being the most certain characteristics of physical and mental developments without consciousness and aims. So plays become sources of entertainment and happiness for children. Also, children get ready for work life, social and real lives step by step by meeting and developing children's tendencies (15).

What a small child does in a play helps to recognize his environment. This increases his experiences in his development process. The one makes a relation between objects and events. Then perceptual invariances, inferences develop, so a child has ability for understanding and organizing his environment. A system of concepts occurs in a child when his doings, perceivings, learnings comply with the other persons. The style of thinking keeps away from selfishness. Social opinions appear (26).

As one of the most important needs of children, their social experiences are shaped while playing. A child starts to learn his upcoming roles via plays. He harmonizes with playmates, knows them better and strengthens his relations. In general, child plays consist of playing houses, block plays, imaginative plays and dramatic representations. It is based on an adult's life. When a child gets older, he is naturally involved in a more positive communication with his friend during plays (28).

Child plays are considered to be amusable but aimless. In reality children show and check most of senses-movements and cognitive skills in plays. They develop concepts, social awareness and social behaviors. Even they increase coordination and balance during run or jump on the beach, on the school way. The same effect is also provided with more narrowed ways by iceskating, rollerskating, turning sticks in the air, walking on long sticks, cycling, playing frisbee golf (14).

In light of this information, here it was studied to determine the effects of play on the period which is called "Pre-School Age", in other words, "Play Period", and involves the ages between 3-6 among the children.

\section{Play in 3-6 age period}

The first developed theories about plays started to explain why people and animals needed to play. Then the theories were developed on the dynamics of play. Rousseau, Montessori, MacMillan brothers, Suzan Isaacs warned the society, saying that children had more different requirements than adults, and these changed in ages. Recently this movement has become a model in itself in the west world, some schools have tried to arrange the education programs only to give children education in a play environment (29).

According to Vandalen \& Bennett (33), the disciplines such as civilization history and archeology support the child plays are as old as cultures. Studies show that children had education by imitating adults in play activities in American natives, African natives and Australian aborgines. Survival skills were taught to children in play activities as well, male children performed their motor skills, physical courage, strength and endurance skills accompanied by dance show and fire in sect ceremonies (18).

Pre-school children leave behind baby period and exceed limitations of baby cots. They can move, apply force to objects, and keep their balances in response to the gravity force. An effective movement development makes children move freely and control their bodies. Children trying to learn moving are always involved in researching, analysing, discovering, practising and making decisions. As the one learns to move, the one moves to learn (23).

The period between the ages 3-6 named "PreSchool Age" is one of the most important periods of childhood. This period is called "Play Period", too. In this period, children are talkative, chirpy, lively and lovely beings. They ask without stopping. They want to know, recognize everything. As they talk and ask without stopping, they play without getting tired, bored all day. They look for a friend in their plays. Pair and triple plays begin. They are inclined to have a relationship with their peers, play together and share. In other words, they are on the way of being a small member of society (31).

In pre-school period (3-4-5-6 ages) children represent different characteristics in their ages. At the ages of 3-4, children are energetic, they reflect this dynamism on their all behaviors, even though they show a great interest to perform a number of 
motor activities alone, they may not always achieve in best results. In the age group of 4-5, children have more psychological, motor and behavioral balances, consider what happens in their environment, have a capacity of imitating and wandering. Children in the age group of 5-6 have more capacities to perceive rather than the previous periods and are in effort to learn letters and numbers even though they have physical weakness and do not have harmony with the environment (16).

In development of motor skills in pre-school period, the effects of gender start to appear. In this process, the gender difference is in favour of boys in jump, vertical jump and sprints. On the contrary, girls are more superior than boys in skills requiring coordination and balance since they skip a rope and play hopscotch more. In next years, the gender difference appears more clearly. Tests pertaining to this period show that boys run faster, shoot and jump more powerfully, and become more endurable and steady in some balance skills rather than girls. But these differences are insignificant values when compared to the differences of adolescence period. On the other hand, girls are more advantageous than boys when mentioned about flexibility as a motor feature (24).

Pre-school education institutions must be ones which give importance to children's verbal activities and make them act in a relaxed way. In these institutions colors, numbers and concepts are given in concrete items in accordance with children's thoughts. Finger painting and art activity, water play, sand play, rhytmical gymnastics, plays with blocks are among the leading play series. The dramatic play corners children mostly like are professional corners of doctors, babies, and groceries. Children observe the best and organized play environment in the institution. So children's potentials show up themselves in an environment where the ones become free and express their emotions freely (35).

It is known that plays directly affect all developments of children. This effect is a recognized fact that each play impresses a child's development as a whole even if it differs from its characteristics.

\section{Effects of play on physical and motor developments}

An individual's movements integrated with his mental life are called psycho-motor behaviours.
When a child is born, he has psycho-motor abilities such as readiness for reaction, speed, stabile movements, coordination, dynamic core and flexibility. Play environments develop these abilities healthily. Thanks to plays, his psychomotor skills increase, he takes his large-small muscles under control, his organs provide coordination and balance, he has an increasing strength and endurance in his muscles, flexibility and agility in his movements (31).

A child, who plays an active play for the first time, learns it with his mind, with his muscles as well. Whenever he plays the same play, both his mind and his muscles reinforce the movements relating to that play. As a result of this, a type of muscle memory occurs. A child, who plays an active play for many times, can easily perform the movements relating to that play with his muscle memory without using his mind so much. Muscles can do the movements they learn before more easily rather than the movements they do not know. This easiness accelerates, strengthens muscle development. It makes development healthy (19).

Byers (10) stated the basic physical education activities practised in a different approach were undertaken to be newly designed for pre-schools. Total 84 activities were divided into 6 categories including "perceptual-motor skills, basic movement skills, manipulative skills, rhytmical activities, gymnastics and plays". Finally, it was given that a good play needed perceptual skills of 10.71 , basic motor skills of $13.10 \%$, manipulative skills of $21.54 \%$, rhytmical activities of $19.05 \%$, gymnastics of $9.52 \%$, and plays of $26.19 \%$. The average for each category was regarded to be $16.7 \%$. Byers also said that the basic physical education program must provide motor skills, mental learning, emotional learning and physical fitness development.

Tyson (32) made a research on 138 subjects to determine the effects of planned play activities on the development of motor skills. 138 subjects' motor test measurements were done as pre-tests and post-tests, the experimental group was given to practise play activities relating to strengthening especially shoulders and buts for 31 days after the pre-test. The same measurements were done as post-tests. Finally, any significant difference was not found in the motor capability of the experimental group. 
Küçükkaya's (20) study focused on the place and importance of plays in the motor development of girls and boys aged 5-6. In the study 41 children participated, the uncontrolled pre-post test models were used. An observation form with 100 target behaviours was prepared, 60 plays were performed to acquire the target behaviours with a play application for 60-90 minutes each day during 3 months. To sum up, it was emphasised that $85 \%$ of 100 target behaviours required was positively taken, $15 \%$ of them was not taken. Plays containing the target behaviours were effective means of making children's motor developments.

Zachopoulou et al. (30) researched the effects of music and movement programs on the motor performance in the children aged 4-6. 90 children including 42 girls and 48 boys took part in the study, 50 of them was included in the music and movement program as an experimental group for 35-40 minutes twice a week during 2 months. The control group continued the physical education courses in the same process. MOT 4-6 was used in measuring the children's jump and dynamic balance skills. The results of the study indicated that the measurements of jump and dynamic balance were significantly high in the children involved in the music and movement program, that the program positively influenced these skills.

In Çelebi's (12) study, 60 students in the age group of 5-6 participated to analyse whether the practised movement education affected the children's physical and motor developments among the children aged 5-6 who went on preschool education institutions. The children in the experimental group took part in the movement education program of total 24 courses for 45 minutes 3 days in a week during 8 weeks. As a result, the planned and long-term movement education program positively impressed some physical characteristics of children aged 5-6 (body weight, BMI, biceps, triceps, and subscapula) and positively increased their motor performances.

\section{Effects of play on emotional - social developments}

The first childhood experiences create a basis of social and emotional developments in school period. Walking and speaking skills the one acquires in small childhood or the autonomous period partly save a child from the desperation of infancy period. As he enjoys these skills he acquires lately, he begins to taste freedom. But some prohibitions appear even if he does not think about these. When they are given freedom about their abilities in a certain way, a healthy development is expected from themselves. Preschool or play period is one of the most colorful ages of childhood.

Children research, discover and learn in plays. They meet others and get in contact with their peers. Also, they find opportunities to keep away themselves from their fears, anxiety and aggressiveness. Improvisational socio-dramatic plays support imaginative power, productivity and reasoning. Plays function as a means of encouraging social behaviors (29).

Putting oneself into someone's shoes or seeing oneself in someone's shoes is the most difficult stage for children's social development. For this development, they must be able to imitate, change the reality in the imaginative world, make a good relationship and communicate well. Especially, the last two characteristics are valid for "role plays" (26).

Children must be tolerant to other children from different cultures and different environments during play and have good relationships with them. Because playing continuously together depends on this. Children both learn to be easygoing with each other and know the society involving themselves and other individuals in plays. They obtain information about their social roles and professions (17).

Children never ask how plays are invented while playing. In many situations, plays and toys do not have any certain starting point. However, there is a natural development process which society, traditions and etimology play an important role. The recent form of a play is the recent situation of a long process. But it is necessary to consider that many plays and toys have not changed in terms of content for centuries so much. Plays are natural instruments which affect children's current and future relations and make them improve their social and cognitive skills. Researching developments and functions of plays is necessary to create environments appropriate for children's development and understand children's experiences better (25).

Owing to plays, children take their emotional reactions under control, keep away from their problems, believe in themselves, take pleasure, feel love and admiration. This is a significant contribution for their emotional development (3). 
In Lindsay's study (21), the play field activities at 10 Alberta nursery schools were analyzed to determine the gender differences in plays. It was finally stated that females were more social and collaborative than males in play, females' collaboration focused on process rather than conclusion. Male plays were aimed at concluding and winning more. Competition and collaboration elements were in a balanced order in play groups where female and male children were mix.

\section{Effects of play on psychological (personality) development}

No matter how simple plays are, they certainly have some effects on players. As children learn respect to others, they also learn respect to themselves. While they are respectful to others' rights, they struggle for protecting their own rights, and while they show respects, they learn to struggle. Thus, they become more ambitious for struggle. In group plays, managing and being managed are matters of subject. In such cases some children want to put across their opinions, manage others and start to influence mutually. These children improve management, leadership qualities. Since honesty is preferred in plays, children find out that honesty gives prestige to people, and they internalise honesty. To win the game, players must try different choices, undertake different enterprises. With its feature, plays make passive ones active, cowards brave. Personal characteristics such as believing in oneself, auditing oneself, making quick decisions, cooperating, being truthful, protecting rights and having disciplines are acquired in plays (17).

Children have sexual genders with plays, learn their own responsibilities and individuals' personalities by taking over the roles of family individuals. They perceive professional groups and their roles in plays. They discover problemsolving together (2).

Children, who play a game, become overwhelmed and show their real personality. They introduce themselves to everybody at all points. Personality characteristics such as leaders, jellyfish, buzzkillers, fighters, administrators, idlers, hardworking ones appear in plays.

A different research by Al-balhan (4) analyzed the relations of children with peers, families and teachers during plays on a different approach. A program developed by teachers, experts, nurses and psychologists from 5 Kuveyt kindergartens was exposed for 10 weeks. At the end of program, significant increases were observed in skills and information of children at kindergartens.

Falcone (13) studied the effects of the developmental education program on selfconfidence, respect to others and behaviours appropriate for primary schools in 5 children. The education program consisting of playing, writing, drawing and making puppet shows was done at the $3^{\text {rd }}$ class and children's behaviours were evaluated at the $4^{\text {th }}$ class. At the end of the study, it was determined that children made progresses in school environment in terms of feeling confident, respecting to others and school rules, achieving academic successes and the program was welldone (18).

\section{Effects of play on intelligence (mental) development}

Plays are means of communication. During socialization, children learn to comply with the rules and values of the group. This learning keeps on from birth to death during all lives and in this process individuals' relations with people and their harmonisation in their environment play important roles. While playing, children use the instruments around themselves. When using toys, tools and equipments, children learn body parts and muscles in a controlled way, and how to use what, how to play. When the age becomes older, children want to play with others together more, interact with them.

The most leading effect of plays on the mental development is learning. By noticing each kind of objects and concepts in plays, children find out their usage characteristics and functions. This learning is a mental development in terms of information accumulation and study. Children become active at the play time in terms of mental ways such as continuously thinking, understanding, perceiving and symbolising and abstract abilities. This is one of the important factors supporting the mental development (17).

Children build lots of cognitive abilities while playing a game. Decision-making, memory, strategy, observation, spatial reasoning, problemsolving, and creative thinking are some of the important cognitive skills. With many table plays (riddle, ludo, playing cards), they practice recognizing, spelling, reading and counting letters, numbers and colors (14). 
Plays are regarded as a wonderful order for the cognitive development. They especially deal with the fictionalised and symbolic aspects of plays. For instance, children using a stick like a horse... Imaginative situations are real for children. Parents must encourage children for imaginative plays similar to these because they foster children's cognitive development, particularly their creative opinions. As Arnold (19) stated, all experiences shared by mothers-fathers and children enhance information storage of children. These must be included in plays if possible.

Play activities may be considered as starting for the reading-writing process when children become older. After many studies, it has been revealed that plays and toys are very beneficial in developing productive thinking (28).

Free environment in any play influence children's mental development. When any problem occurs in plays and is solved by players, children's capability for problem-solving goes ahead, thus, this helps the mental development.

Bernd (8) researched about the effects of symbolic plays on the problem-solving strategies in children. In this study 90 children aged between 4-8 participated, the children were divided into three groups including symbolic play, group play and control group, two duties of problem-solving were given to children after play. As a result of the study, older children were recorded to be more successful than smaller ones in solving problems. The symbolic play group was stated not to be as successful as other two groups.

Lorenzi (22) observed the normal and mentally disabled children during free plays in his study aimed at the comparison of play and movement characteristics of two different groups. Total 140 children took part in the study. The results of the study showed that the activity number was more in children with mental disabilities than normal children. In both groups the activity number of males was more than females.

\section{Effects of play on linguistic development}

Children love finger plays performed by seeing, saying and doing because it has a separate feature of doing as well as learning something. Finger plays are activities which are performed by linking words with movements and take significant roles in preparation for dramatic plays.
In order to use this one effectively, a teacher is required to memorise words, this one-related movements. When children repeat words with a teacher, they perform movements. Finger plays are effective for children in learning some concepts (34).

Plays make great contributions in children to express and tell something. Utterances which children make to express their happiness and anger while playing a small bell, a ball, etc. in their hand are their first speeches. These sounds without meanings turn into meaningful ones in time. When they play with their peers in the ages of 4-5, they try to speak in accordance with their own role. In all of plays children make a dialogue with each other after the age 5 . These things affect children's linguistic development in a positive way.

Collectively performed group plays, sociodramatic plays inspired from child stories, puppets, rhymes, riddles and poems, ronds, story books are language-based plays. These plays which gain importance in the process of socialization, affect children's development in the cognitive field positively. In any play environment, children's linguistic development begins when they give opinions about their experiences. Language is an expression way of a process with various movements, mimics, imitations, smiles, curiosity questions and sudden discoveries (29).

Casby \& Della Corte (11) compared the relations between language performances and symbolic plays as replacing objects in the children involved in the first three language development stages defined with regard to Brown's (9) average word length. The results of the study support the view that symbolic plays are associated with early language development especially in the process of word combining. In the same study, symbolic play skills are more different among children involved at the level of word-combining level of language development than children involved at the monosyllable level and these children are more successful in symbolic plays which require an object must be used in place of another object. The relation between symbolic plays and language is stronger than the relation between symbolic plays and chronological ages, which is among the prominent findings of the study (1). 


\section{DISCUSSION}

This study focused on the importance of play for children in the period which is called "PreSchool Age" or "Play Period" and includes the ages between 3 and 6 .

Plays are activities which develop children's physical and mental abilities, give pleasure in their lives, and enhance language and socialization skills. They are children's real lives. Parents or teachers will have an opportunity for evaluating children's personality with the help of plays at best by observing children's behaviours. While playing, children are under the effects of their current environment, their family, their own genetical intelligence, perception, interpretation and creative characteristics. When these children come to the school period, plays become more conscious and regular.

According to Freud, children reveal emotions and behaviors which are not accepted in a safe environment and can be aggressive and dangerous in a real life, via plays as soon as they get rid of obstacles and prohibitions of the real world. When Freud mentions about the repeated obsessions, they pay attention to the characteristics of making skills and overcoming with something via plays. These repeated behaviours are psychic mechanisms and become effective in conquering individuals' fears (30).

Piaget's play theory is based on the cognitive development. According to Piaget, the development of human intelligence depends on assimilation and adaptation proceedings. Piaget considers play as a way of placing the thing from the outer world into this system. According to this, play is an important issue which is always available in human behaviors and supports children's mental development (7).

Piaget stated that logical thinking would not only be about children's interests in objects. Also, he added it would develop when they play with other children, working together, making efforts in a group, talking to each other are significant for mental development (26).

Ericson dealt with play in the light of the psycho-social development theory and evaluated it in this concept. He emphasized that play was a mirror of a child's psycho-social development and it differed in development periods. Erickson focused on the effects of play on the selfdevelopment (30).
According to Montessori (1870-1952), play is a child's work. That is, these are activities associated with learning. Montessori stated that the prizepunishment application in education made selfdiscipline acquisition difficult. He expressed that opportunities must be given children to choose their own friends by themselves and make decisions for play choice. Montessori gave importance to adults to play with children together. He indicated that children could perform plays with education materials to learn. Montessori did not give any importance to imaginative plays, stressed that plays must involve aims (30).

As Poyraz (28) claimed, children completely devote themselves to play without thinking the aim and privileges of play and while playing, and what they experience via plays without noticing, provides benefits for their next life. Plays teach children not to expect something in return, to feel happy while doing some things. Children, who learn this, know to make sacrifice when they grow up, remain at the forefront or in the background from time to time. Children learn their environment and many properties, realities of the society via plays. During plays, children's emotions run. Their movement skills, their intelligence and logics, their curiosity, perception and skills develop.

In Patrick's (27) opinion, plays develop social skills. Lack of social skills generally causes behavioral problems. Plays lay emphasis on depressed feelings. Children can change their fears, angers and ambitions into activities in plays. Plays are important activities which recover individuals from stress. Owing to plays, children learn their personal characteristics and understand others' viewpoints. They learn justice, harmonization with rules, collaborative works, friendship via plays. These social abilities enhance their self-respect (19).

In conclusion; playing, jumping, running, shortly, moving take an important place in children's education and personality development. Also, they help children to get in contact with their environment (supporting their social development), to reflect their emotions (supporting their emotional development) and opinions (supporting their language development and cognitive development).

An effective movement development provides children opportunities to move freely and 
control their bodies. They learn to move, furthermore, they move to learn. Children, who move, develop a capability of problem-solving and look for new ways and creative solutions in order to express their self-respect. When they perform these activities, they use and develop their basic characteristics such as considering, focusing on one dimension which are important for the cognitive development during all their lives. Since children grow up by moving, body movement is as necessary as their food. In this regard, it seems to be indispensable to create an environment appropriate for their running, climbing, jumping, leaping and let children do these things.

\section{REFERENCES}

1. Acarlar F. Sembolik Oyunun Dil Gelişimi ve Dil Bozukluklarıyla İlişkisi, Özel Eğitim Dergisi, 3(1), 25-33, Ankara, 2001.

2. Akandere M. Eğitici Okul Oyunları, Nobel Yayıncılık, 1. Bask1, Ankara, 2003.

3. Akandere M. Eğitici Okul Oyunları, Nobel Yayıncılık, 3. Bask1, Ankara, 2006.

4. Al-Balhan E. Training Kuwaiti kindergarten professionals in knowledge of child development, facilitation, strategies and developmental analysis through the transdisciplinary playbased assessment techniques, University of Denver, Doctor Of Philosophy UMI, USA, 1998.

5. Arnold A. Çocuğunuz ve Oyun (Çev. Gümüş, A), Oğul Matbaacilık, İstanbul, 1995.

6. Aslan F. Identification of the features of child's games and toys, aged between 1-3, through the development theory. Journal of Cumhuriyet University School of Nursing, 2000; 4(2): 40-43.

7. Baykoç Dönmez N. Üniversite Çocuk Gelişimi ve Eğitimi Bölümü ve Kız Meslek Lisesi Öğrencileri İçin Oyun Kitabı, 1. Basım, İstanbul: Esin Yayınevi, 2000.

8. Bernd A. The effects of play on problem solving, Doctoral Thesis, Long Island University, UMI, USA, 1996.

9. Brown R. A First Language: The Early Stages, Harvard University Press, Cambridge, MA. 1973.

10. Byers MR. A physical education activities instructional manual for Pk-3 grades for elementary education and physical education majors. Master Thesis, Central Missouri State University, UMI, USA, 1997.

11. Casby MW, Della CM. Symbolic play performance and early language development. Journal of Psycholinguistic Rescarh, 1987; 16(1): 31-42.

12. Çelebi B. Hareket Eğitiminin Okul Öncesi Eğitim Kurumlarındaki 5-6 Yaş Grubu Çocuklarda Fiziksel ve Motor Gelişime Etkisi, Institute of Social Sciences, 2010.

13. Falcone G. The Impact of a Developmental Guidance Program on Five Fourth Grade Students in a Suburban School District: Clinical Case Study, Widener University, Doctor of Education, USA, 1999.
14. Gander JM, Gardiner WH. Çocuk ve Ergen Gelişimi, 7. Baskı, Çeviri: Ali Dönmez, H. Nermin Çelen, Bekir Onur, Ankara: İmge Kitabevi Yayınları, 2010.

15. Güneş A. Okullarda Beden Eğitimi ve Oyun Öğretimi, 4. Baskı, Ankara: Pegem A Yayıncılık, 2004.

16. Günsel AM. Okul Öncesinde Beden Eğitimi ve Uygulamaları, Ankara: Anı Yayıncılık, 2004.

17. Hazar M. Beden Eğitimi ve Sporda Oyunla Eğitim, Tutibay Yayıncilık, Ankara 2000.

18. Kerkez F. Oyun ve egzersizin yuva ve anaokuluna giden 5-6 yaş grubu çocuklarda fiziksel ve motor gelişime etkisinin araştırılması. Doctoral Thesis, Institute of Social Sciences, Karadeniz Technical University, Trabzon, 2006.

19. Kuru O. Dokuz yaş çocuklarin psikomotor gelişimlerinde oyunun etkisi. Master Thesis, Institute of Social Sciences, Firat University, Elazı̆̆, 2009.

20. Küçükkaya El. Okulöncesi 5-6 Yaş Kız ve Erkek Çocukların Motor Gelişimlerinin Sağlanmasında Oyunun Yeri ve Önemi, Uludağ Üniversitesi, II. Ulusal Beden Eğitimi ve Spor Öğretmenliği Sempozyumu, Bursa, 2001.

21. Lindsay PL. The physical characteristic of playground games in public elementary schools in Edmonton. Canadian Association for Health, Physical Education and Recreation Journal, 1984; 50: 8-11.

22. Lorenzi DG. Comparison of activity levels during free play of elementary school aged children with and without mental retardation. Master of Arts, University of Pennsylvania, USA, 1998.

23. Mengütay S. Çocuklarda Hareket Gelişimi ve Spor. İstanbul: Morpa Kültür Yayınları, İstanbul, 2005.

24. Muratlı S. Antrenman Bilimi Işs̆ğı Altında Çocuk ve Spor. Ankara: Bagırgan Yayımevi, 1997.

25. Öğretir AD. Play and the play therapy. The Journal of The Industriel Arts Education Faculty of Gazi University, 2008; (22): 94-100.

26. Özdoğan, B. Çocuk ve Oyun, Çocuğa Oyunla Yardım. Genişletilmiş 5. Baskı, Ankara: Anı Yayıncılık, 2009.

27. Patrick T. Play: An Important Component of Preventative Behavior Management, Arkansas: Archild Inc., 1996.

28. Poyraz H. Okul Öncesi Dönemde Oyun ve Oyuncak. Ankara: Anı Yayıncilık, 2003.

29. Sevinç M. Erken Çocukluk Gelişimi ve Eğitiminde Oyun. İstanbul: Morpa Kültür Yayınları Ltd. Ş., 2004.

30. Sevinç M. Erken Çocuklukta Gelişim ve Eğitimde Yeni Yaklaşımlar. 1. Basım, 2. Cilt, İstanbul: Morpa Kültür Yayınları, 2005.

31. Seyrek H, Sun M. Okul Öncesi Eğitiminde Oyun. 5. Baskı, İzmir, 1999.

32. Tyson DA. The effects of intervention activities on motor skills in kindergarten students. Doctoral Thesis, Texas Avem University, USA, 1998.

33. Vandalen DB, Bennett B. A World History of Physical Education Cultural Philosophical Comparative, Prentice Hall Inc., Second Edition, Englewood Cliffs, N.J., 1971.

34. Yalçın H. Çocuk Gelişimi. 1. Basım, Ankara: Nobel Yayın Dağıtım Tic. Ltd. Şti., 2010. 
35. Yavuzer H. Çocuk Eğitimi El Kitabı. 27. Basım, İstanbul: Remzi Kitabevi, 2011.

36. Zachopoulou E, Aggeliki T, Vassiliki D. The effects of a developmentally appropriate music and movement program on motor performance. Early Childhood Research Quarterly, 2004; 19: 631-642. 